УДК 378.011.3-051:316.647.5

(C) Попова О.В., Жуков В.П., 2020

http://orcid.org/0000-0003-1611-5956

http://orcid.org/0000-0002-7845-6222

https://doi.org/10.34142/23128046.2020.49.06

O. В. Попова

В. П. Жуков

\title{
ПЕДАГОГІЧНЕ ЗАБЕЗПЕЧЕННЯ ПРОЦЕСУ ПІДГОТОВКИ МАЙБУТНІХ УЧИТЕЛІВ ДО ВИХОВАННЯ ТОЛЕРАНТНОСТІ ШКОЛЯРІВ
}

У статті доведено актуальність спеціальної підготовки майбутніх учителів до виховання толерантності иколярів. Розкрито суть толерантності як соціально та особистісно значущої цінності, котра виступає як інтегрована моральна якість особистості, що відбиває активну моральну позицію і підготовленість до конструктивної взаємодії з людьми $i$ групами незалежно від їхньої національної, сочіальної, релігійної приналежності, поглядів, світогляду, стилю мислення $i$ типу поведінки (виключаючи асочіальні прояви свідомості $i$ поведінки). 3'ясовано суть $i$ структуру готовності майбутнього вчителя до виховання толерантності школярів (далі-ВТШ).

Визначено педагогічні умови процесу підготовки майбутніх учителів до виховання толерантності школярів, що передбачають: формування професійної спрямованості майбутніх учителів на підготовку до ВТШ; створення толерантного освітнього середовища, в основу якого покладено принциипи гуманізму, демократизму та педагогічної деонтологї; оволодіння студентами необхідними професійними знаннями ци уміннями, моральноетичними якостями, а також відповідним навчально-методичним інструментарієм (методами, формами, засобами) щодо ВТШ у різних видах діяльності: навчальній (аудиторній, позааудиторній), виховній, педагогічній практиці тощчо.

Презентовано комплекс педагогічних засобів забезпечення визначених умов досліджуваної підготовки (бінарні лекції $i$ семінари, щุо проводяться викладачем і студентами-старшокурсниками з метою мотиваџії, ділового співробітничтва та обміну практичним досвідом; тренінгові заняття з розвитку толерантності як професійної якості $i$ особистісно значущої цінності; відеометод; метод створення виховних ситуацій; курс за вибором «Педагогіка толерантності», технологія тематичного портфоліо та ін.).

Автори статті вважають, що в подальшому науковиям слід більше уваги приділяти формуванню готовності майбутніх педагогів до ВТШ у таких 
важливих видах професійної підготовки, як педагогічна практика, позааудиторна виховна робота, волонтерська діяльність, студентське самоврядування, що має стати перспективними напрямами подальших наукових розвідок у означеному напрямі. Також потребує більшої уваги вчених звернення до процесу формування методичної складової готовності майбутніх учителів до ВТШ.

Ключові слова: майбутній учитель, школяр, толерантність, виховання, підготовка, педагогічні умови, форми, методи, засоби.

Popova O. V., Zhukov V. P. Process of pedagogical support of future teachers training for school children's tolerance education. The article proves the relevance of special training of future teachers for school children's tolerance education. The essence of tolerance as socially and personally significant value is revealed, which acts as an integral moral quality of personality, reflecting active moral position and readiness for constructive interaction with people and groups regardless of their national, social, religious affiliation, views, worldview, style of thinking and type of behavior (excluding antisocial manifestations of consciousness and behavior). The essence and structure of readiness of future teacher for school children's tolerance education is found out.

The pedagogical conditions of process of future teachers training for school children's tolerance education are defined, that provides: stimulation of professional orientation of future teachers on preparation for STE; creation of tolerant educational environment based on the principles of humanism, democracy and pedagogical deontology; students' mastering of necessary professional knowledge and skills, moral and ethical qualities, and also the corresponding educational and methodical tools (methods, forms, means) concerning STE in various kinds of activity: educational (classroom, out-of-class), educational, during pedagogical practices, etc.

A set of pedagogical tools to ensure certain conditions of study is presented (binary lectures and seminars conducted by teachers and senior students to motivate, business cooperation and exchange of practical experience; training sessions on the development of tolerance as a professional quality and personal value; method of educational situations; method of educational situations; elective course "Pedagogy of Tolerance", thematic portfolio technology, etc.).

The authors of the article believe that in the future scientists should pay more attention to the formation of readiness of future teachers for STE in such important types of training as teaching practice, extracurricular educational work, volunteering, student government, which should become promising areas of further research in this area. Scientists also need more attention to pay attention to the process of forming the methodological component of the readiness of future teachers for STE.

Key words: future teacher, school child, tolerance, education, preparation, pedagogical conditions, forms, methods, means. 
Вступ. Для багатоетнічної, полікультурної України найважливішим орієнтиром сучасної освітньої політики $є$ виховання особистості, яка шанобливо ставиться до думок, поглядів, цінностей інших людей, здатної до міжкультурного діалогу та взаєморозуміння з представниками різних культур, релігійного сповідання тощо. Тож особливої актуальності набуває виховання толерантності школярів (далі - ВТШ), котра за сучасних умовах стає, з одного боку, основою освіти, яка транслює норми людських відносин, 3 іншого, інструментальною цінністю особистості, яка визначає ії ставлення до світу і його поведінку у взаємодії з іншими (Akhkyiamova, n. d.).

Процес ВТШ викликає у вчителів чимало труднощів. Часто педагог буває не готовий до продуктивної педагогічної діяльності в цій галузі, що пов'язане, передусім, із рівнем його професіоналізму, але в деяких випадках педагог просто не володіє для організації такої роботи належною професійною готовністю. 3 огляду на це важливим завданням вищої педагогічної освіти $\epsilon$ спеціальна підготовка вчителя до ВТШ, що передбачає опанування необхідними теоретичними знаннями, вміннями $\mathrm{i}$ навичками, а також формування в майбутнього вчителя толерантності як професійної особистісної якості педагога.

Теоретико-методологічні засади педагогіки толерантності розкрито у працях Я. Берегового, Л. Завірюхи, В. Кременя, Н. Невінчаної, В. Титова, Ю. Тодорцевої та ін. На вагомості толерантності як особистісної та професійної риси у діяльності вчителя наголошено у наукових працях М. Андрєєва, О. Безкоровайної, Р. Безпальчі, Н. Бирко, О. Булгакової, Д. Зіновєва, О. Левченко, О. Матієнко та ін. Осмислення проблеми формування толерантності знайшло відображення у дослідженнях психологів (О. Асмолов, І. Бех, О. Клепцова та ін.) і педагогів (Л. Бернадська, Б. Вульфов, О. Грива, О. Савченко, О. Столяренко та ін.).

Питання формування толерантності у процесі професійної підготовки майбутнього вчителя розкрито у дослідженнях Т. Білоус, Л. Завірюхи, Д. Зінов'єва, О. Ісаєвої, П. Комогорова, Ю. Тодорцевої. Проблемі підготовки майбутнього вчителя до ВТШ присвячені дослідження Г. Ахкиямової, Т. Варенко, Р. Кострубань, А. Погодіної, А. Ремньової, І. Сухопари, Л. Чередник та ін.

Мета та завдання. Мета статmі полягає у з'ясуванні суті та змісту підготовки майбутнього вчителя до виховання толерантності учнів, визначенні педагогічних умов означеного процесу та презентації їх педагогічного забезпечення.

Методи дослідження. Під час наукового пошуку використовувався комплекс методів дослідження: теоретичних (теоретичне узагальнення наукових ідей i поглядів, викладених у філософській, педагогічній, психологічній літературі 3 проблеми дослідження; проектування i моделювання, аналіз педагогічного досвіду, причинно-наслідковий аналіз 
отриманих емпіричних даних); емпіричних (дослідно-експериментальна робота, спостереження, анкетування, тестування, бесіда, самооцінювання студентів, експертна оцінка).

Результати. Толерантність (від лат. tolerantia - терпіння) у довідковій літературі визначається як інтуїтивне сприйняття єдності людства, взаємозалежності всіх від кожного й кожного від усіх, полягає в повазі прав іншого (у тому числі права бути іншим), а також утриманні від завдання шкоди для всіх і для самого себе; як відсутність чи послаблення реагування на якийсь несприятливий чинник унаслідок зниження чутливості до його впливу; як якість, котра виявляється в підвищенні емоційного реагування на загрозливу ситуацію, а зовнішньо - у витримці, здатності протягом тривалого часу зазнавати несприятливих впливів без зниження адаптивних можливостей (Honcharenko, 1997; Petrovskii \& Yaroshevskii, 1990; Gubskii, 1999).

На основі аналізу наукових джерел (Honcharov, 2013; Pohodyna, 2006; Remnyova, n. d.; Popova \& Guzenko, 2020), професійну підготовку майбутнього вчителя до ВТШ визначаємо як процес, який забезпечує особистіснопрофесійний розвиток майбутнього вчителя, спрямований на оволодіння студентами необхідними загальнопедагогічними і спеціальними знаннями, вміннями та навичками, формування в них професійно важливих особистісних якостей та здібностей, котрі забезпечують успішність професійно-педагогічної діяльності в означеному напрямі. Результатом такої підготовки $є$ відповідна готовність, яку розглядаємо як психолого-педагогічне новоутворення особистості майбутнього вчителя, як одну з найважливіших цілей діяльності педагогічних закладів вищої освіти і кінцевий результат цієї діяльності, який являє собою сукупність мотивів, цінностей, знань, умінь і навичок, а також професійно важливих якостей особистості, котрі повинен мати майбутній педагог для успішного ВТШ.

Готовність до ВТШ як інтегрована професійно-особистісна якість учителя має певну структуру, яку необхідно в першу чергу враховувати під час визначення педагогічних умов відповідної професійної підготовки майбутніх учителів. На основі вивчення наукової літератури (Honcharov, 2013; Andrieiev, 2006; Beziuleva, Bondyreva \& Shelamova, 2005; Cherednyk, 2019) у структурі вказаної готовності майбутнього вчителя виокремлюємо мотиваційноаксіологічний, когнітивно-світоглядний, інструментально-методичний і особистісно-рефлексивний компоненти.

Ураховуючи наукові здобутки вчених із досліджуваної проблеми (Bida, 2017; Hryva, 2007; Korets, Nikitina \& Romanenko, 2009; Kostruban, 2016; Pohodyna, 2006; Tretiakova, 2009) нами визначено педагогічні умови підготовки майбутніх учителів до ВТШ, які передбачають:

1) формування професійної спрямованості майбутніх учителів на підготовку до ВТШ (професійних мотивів, позитивного ставлення до проблеми виховання толерантності та цінності толерантності, єдності установок на виховання толерантності у школярів i власне толерантну поведінку в 
професійній і особистісній сферах життєдіяльності, усвідомлення необхідності спеціальної підготовки до ВТШ);

2) створення толерантного освітнього середовища, в основу якого покладено принципи гуманізму, демократизму та педагогічної деонтології;

3) оволодіння студентами необхідними професійними знаннями й уміннями, морально-етичними якостями, а також відповідним навчальнометодичним інструментарієм (методами, формами, засобами) щодо ВТШ у різних видах діяльності: навчальній (аудиторній, позааудиторній), виховній, педагогічній практиці.

У процесі реалізації першої із визначених умов викладачі ознайомлювали студентів із новими парадигмами розв'язання найгостріших проблем сучасного людства, прагнули усвідомлення майбутніми вчителями ідеї цілісноплюралістичного, універсально-унікального характеру історичних подій, налаштовували на оптимізацію розв'язання суперечностей між протилежними тенденціями, демонстрували єдину можливість конструктивного урегулювання стосунків між конкуруючими цивілізаціями, культурами, соціальними групами чи окремими людьми на основі толерантності (Deklaratsiia pryntsypiv tolerantnosti, 1996; Todorovtseva, 2004).

Це сприяло усвідомленню майбутніми вчителями значущості ВТШ, формуванню професійної спрямованості студентів на підготовку до ВТШ, розвитку установки на толерантність як важливої професійної якості сучасного педагога. Професійна спрямованість на підготовку до ВТШ сприяла зміцненню переконання студентів у тому, що суперечності, які виникають між представниками різних світоглядів, мають вирішуватися завдяки їх доброзичливій комунікативній взаємодії.

Для посилення педагогічного впливу на формування готовності майбутніх учителів до ВТШ на факультетах університету створювали толерантне освітнє середовище, що передбачало: урахування принципів гуманізму, демократизму та педагогічної деонтології, етизацію міжособистісних взаємин суб'єктів освітнього процесу; створення сприятливого для розвитку толерантності студентів психологічного клімату в різних видах професійної підготовки майбутніх педагогів, умов для професійного самовдосконалення в означеному напрямі, а також естетизацію освітнього середовища для збагаченню емоційно-почуттєвої сфери студентів, яка здатна посилювати стимулювальний вплив на розвиток толерантності студентів.

Для етизації та естетизації сфери спілкування студентів та інших учасників освітнього процесу, гармонізації їх стосунків було організовано проведення сумісного дозвілля (творчі вечори, виїзд до мальовничих куточків природи, відвідування історичних місць Слобожанщини, туристичні походи тощо), під час якого створювалися сприятливі умови для розвитку таких особистісних якостей, як гуманізм, тактовність, доброзичливість, комунікабельність тощо, без яких неможлива толерантна поведінка. Один-два 
рази на тиждень оголошувався «день взаємоввічливості», регулярність проведення якого сприяла вихованню в студентів культури міжособистісних взаємин, стійкої поваги до норм толерантної поведінки.

Із метою створення толерантного освітнього середовища керівництво факультетів, викладачі, куратори груп спрямовували свої зусилля на створення сприятливої психологічної атмосфери в різних видах професійної підготовки, установлення всіх необхідних для формування готовності майбутніх учителів до ВТШ видів комунікативних зв'язків та педагогічної взаємодії на основі реалізації принципів взаємоповаги, взаємодопомоги, толерантності.

Для реалізації третьої з визначених умов підготовки майбутніх учителів до ВТШ було розроблено курс «Педагогіка толерантності» (навчальна дисципліна за вибором), що інтегрує теоретичний, методичний, психологічний аспекти професійної підготовки майбутніх учителів в означеному напрямі.

Завданнями вказаного курсу визначено такі:

- навчити студентів визначати стратегічні й тактичні цілі ВТШ i варіювати можливості їх досягнення в залежності від динаміки зміни соціокультурних умов закладу освіти;

- сформувати компетентності в даній сфері педагогічної теорії та виховної практики;

- оволодіти студентами виховними технологіями та навчальнометодичним інструментарієм ВТШ;

- опанувати майбутніми вчителями діагностикою рівня толерантності школярів.

Під час проведення занять 3 розробленого курсу, 3 урахуванням рекомендацій А. Третьякової (Tretiakova, 2009), дотримувалися таких вимог:

1. Творчість. Завдання, запропоновані студентам, мають носити творчий характер, які вимагають прояву ініціативності, власної позиції, критичного мислення тощо.

2. Колективна діяльність. Більша частина завдань виконується в малих групах. Результати роботи обговорюються всією академічною групою. У колективній діяльності відкриваються можливості для самовизначення i самоствердження студентів, прояву толерантності під час взаємодії.

3. Переведення когнітивного змісту в емоиійний. Викладач відслідковує за допомогою спостереження і опитування студентів, які емоції виникли у них в тій чи іншій ситуації, на початку і в кінці заняття.

4. Атмосфера прийняття. Викладач створює в групі атмосферу прийняття, демонструючи іiі сам і стимулюючи до цього студентів. Викладач виходить із того, що всілякі почуття, навіть дуже негативні, мають право на існування, можуть і мають бути висловлені. Тим самим декларується безумовна самоцінність думки кожної особистості. Атмосфера прийняття сприяє не тільки формуванню толерантності до іншого, а через прийняття інших формує толерантність до себе. 
5. Самопізнання. Самопізнання здійснюється на основі зворотного зв'язку, який студенти отримують від партнерів по спілкуванню, а також на основі діагностування/самодіагностування.

6. Моделювання проблемних (конфліктних) ситуацій з відпраџюванням різних поведінкових стратегій. На заняттях створюється поле для зіткнення інтересів, думок, ідей. Толерантність проявляється в проблемних і кризових ситуаціях, i, відповідно, подібні ситуації $є$ найбільш адекватним полем для іiі розвитку.

7. Діалогово-дискусійний характер навчання. Під час занять стимулюється обмін думками, вираження своїх відносин, емоцій. У діалозі особистість транслює себе, свою унікальність і самобутність. Дискусія як форма діалогу вчить студентів бачити будь-яке явище багатопланово, спонукає до пошуку адекватної аргументації і способів вираження думки; при цьому підвищується сприйнятливість і толерантність до нових ідей.

На заняттях з психолого-педагогічних дисциплін та з розробленого курсу «Педагогіка толерантності» застосовували лекції-бесіди, що забезпечували безпосередній контакт 3 аудиторією, давали можливість привернути увагу майбутніх учителів до найважливіших питань теми; лекції 3 розглядом проблемних або конфліктних ситуацій взаємодії з учнями, що уможливлювали ознайомлення студентів із методами толерантного подолання таких ситуацій; лекції-дискусії, що передбачали вільний обмін поглядами 3 певної проблеми, давали можливість коригувати позиції окремих студентів із метою зміни негативних і хибних установок; бінарні лекції і семінари, що проводилися викладачем і студентами-старшокурсниками з метою поглиблення професійної спрямованості, ділової співпраці та обміну практичним досвідом; семінарські заняття, засновані на інтерактивних методах (діалогово-дискусійні, «брейнстормінг», «круглий стіл», «аналіз ситуацій» тощо).

Серед запроваджених форм $i$ методів підготовки майбутніх учителів у досліджуваному нами напрямі досить ефективними виявилися такі:

- тренінгові заняття 3 розвитку толерантності як професійної якості i особистісно значущої цінності;

- відеометод;

- відвідування різних соціокультурних інститутів, що сприяє зміцненню зв'язку теорії з практикою на основі ознайомлення 3 досвідом виховання толерантності учнів різних вікових груп;

- методи аналізу соціальних явищ та виховних ситуацій, спрямовані на розвиток критичного мислення, ціннісне ставлення до проблеми ВТШ;

- методи моделювання виховного процесу, які спрямовані на оволодіння вміннями цілепокладання, планування, самооцінки, рефлексії;

- участь у науково-дослідній роботі, проєктній діяльності, що відкриває можливості для виховання толерантності у процесі співтворчості;

- долучення студентів до участі в студентському самоврядуванні, волонтерському русі. 
Значну увагу приділяли застосуванню методів діалогової рефлексії, при цьому застосовували такі вправи:

- «Рольова маска» - студентам пропонується увійти в роль іншої людини і виступити від ії особи;

- «Прогнозування розвитку ситуації» - під час бесіди викладач пропонує висловлювати припущення про те, як могла розвиватися та чи інша конфліктна ситуація; при цьому студентами ведеться пошук виходу з ситуації, що склалася;

- «Імпровізація на вільну тему» - студенти вибирають ту тему, в якій вони найбільш сильні і яка викликає у них певний інтерес, переносять події в нові умови, по-своєму, інтерпретують їх зміст тощо;

- «Оголення суперечностей» - розмежування позицій студентів із того чи іншого питання в процесі виконання завдання з подальшим зіткненням протилежних суджень, різних точок зору про відносини різних груп людей;

- «Зустрічні питання» - студенти в малих групах готують певну кількість зустрічних питань. Поставлені питання і відповіді на них потім піддаються колективному обговоренню.

Особливе значення для формування готовності майбутніх учителів до ВТШ мають педагогічні практики, під час яких студенти набувають реального досвіду ВТШ.

Із метою забезпечення процесу підготовки майбутніх учителів до ВТШ на заняттях використовували різноманітні вправи, зокрема такі, як: груп);

- «Естафета» (спрямована на організацію взаємодії студентів із різних

- «Взаємодопомога» (передбачає надання допомоги студентів один одному як умови успіху спільної справи);

- «Акцентування на кращому» (педагог у розмові зі студентами підкреслює кращі риси кожного; при цьому його оцінка має бути об'єктивною і спиратися на конкретні факти);

- «Ломка стереотипів» (під час взаємодії, спілкування студенти мають зрозуміти, що громадська думка не завжди може бути об’єктивною, правильною);

- «Історії про себе» (дає можливість студентам більше дізнатися один про одного і краще зрозуміти один одного. Кожен може скласти історію 3 власного життєвого чи професійного досвіду, пов'язаного 3 проблемою толерантності);

- «Спілкування по правилам» (на період виконання того чи іншого завдання встановлюються правила, що регламентують спілкування і поведінку студентів: у якому порядку, з урахуванням яких вимог можна вносити свої пропозиції, доповнювати, критикувати, спростовувати думку своїх товаришів. Такого роду приписи значною мірою знімають негативні моменти спілкування, захищають «статус» усіх його учасників); 
- «Загальна думка» (студенти «за ланцюжком» висловлюються на тему відносин із різними групами людей: одні починають, інші продовжують, доповнюють, уточнюють. Від простих суджень (коли головним є саме участь кожного студента в запропонованому обговоренні) відбувається перехід до аналітичних, а потім проблемним висловлюванням майбутніх учителів);

- «Справедливий розподіл» (передбачає створення рівних умов для вияву ініціативи всіма студентами; застосовується в ситуації «задавленої ініціативи», коли позитивні виступи і атаки одних гасять ініціативу і бажання спілкуватися у інших. Головне при виконанні вправи - домогтися збалансованого розподілу ініціативи між усіма студентами);

- «Обмін ролями» (студенти обмінюються ролями або функціями, отриманими при виконанні завдань);

- «Мізансцена» (полягає в активізації спілкування i зміні його характеру за допомогою зміни розташування студентів у аудиторії в різні моменти виконання завдання).

Обговорення. Аналіз дисертаційних досліджень і наукових публікацій (Г. Ахкіямова, Т. Білоус, Т. Варенко, О. Ісаєва, Р. Кострубань, А. Погодіна, А. Ремньова, І. Сухопара, Ю. Тодорцева, Л. Чередник та ін.) свідчить про підвищення інтересу науковців до проблеми педагогіки толерантності в цілому і підготовки майбутніх учителів до ВТШ зокрема. Отримані нами результати науково-дослідної роботи в цілому збігаються із здобутками інших дослідників. Водночас, порівняно з попередніми працями, у статті представлено авторський підхід до визначення педагогічних умов підготовки майбутніх учителів до ВТШ, подальшого розвитку набули форми і методи їх забезпечення.

Уважаємо, що в подальшому науковцям слід більше уваги приділити формуванню готовності майбутніх педагогів до ВТШ у таких важливих видах професійної підготовки, як педагогічна практика, позааудиторна виховна робота, волонтерська діяльність, студентське самоврядування, що має стати перспективними напрямами подальших наукових розвідок у означеному напрямі. Також потребує більшої уваги вчених звернення до процесу формування методичної складової готовності майбутніх учителів до ВТШ.

Висновки. Толерантність $\epsilon$ соціально та особистісно значущою цінністю i виступає як інтегрована моральна якість особистості, що відбиває активну моральну позицію і підготовленість до конструктивної взаємодії з людьми і групами незалежно від їхньої національної, соціальної, релігійної приналежності, поглядів, світогляду, стилю мислення i типу поведінки (виключаючи асоціальні прояви свідомості і поведінки). Доведено актуальність спеціальної підготовки майбутніх учителів до ВТШ.

Готовність майбутніх учителів до ВТШ як результат відповідної підготовки розкрито як психолого-педагогічне новоутворення особистості майбутнього вчителя, як одну з найважливіших цілей діяльності педагогічних закладів вищої освіти і кінцевий результат цієї діяльності, який являє собою сукупність мотивів, цінностей, знань, умінь і навичок, а також професійно 
важливих якостей особистості, які повинен мати майбутній педагог для успішного ВТШ. У структурі вказаної готовності майбутнього вчителя виокремлено мотиваційно-аксіологічний, когнітивно-світоглядний, інструментально-методичний і особистісно-рефлексивний компоненти.

Визначено педагогічні умови підготовки майбутніх учителів до ВТШ, що передбачають: формування професійної спрямованості майбутніх учителів на підготовку до ВТШ; створення толерантного освітнього середовища, в основу якого покладено принципи гуманізму, демократизму та педагогічної деонтології; оволодіння студентами необхідними професійними знаннями й уміннями, морально-етичними якостями, а також відповідним навчальнометодичним інструментарієм (методами, формами, засобами) щодо ВТШ у різних видах діяльності: навчальній (аудиторній, позааудиторній), виховній, педагогічній практиці.

Для забезпечення визначених умов досліджуваної підготовки доцільно використовувати різноманітні форми і методи (бінарні лекції і семінари, що проводяться викладачем і студентами-старшокурсниками 3 метою мотивації, ділового співробітництва та обміну практичним досвідом; тренінгові заняття 3 розвитку толерантності як професійної якості і особистісно значущої цінності; відеометод; метод виховних ситуацій; курс за вибором «Педагогіка толерантності», технологія тематичного портфоліо та ін.). Експериментально доведено, що запровадження комплексу педагогічних форм і методів сприяє формуванню стійких навичок толерантної взаємодії студентів і викладачів, допомагає сформувати у майбутніх учителів установку на спеціальну підготовку до ВТШ і саморозвиток у означеному напрямі.

Аналіз сучасного стану проблеми виховання толерантності у майбутніх учителів дає підстави стверджувати, що вона має багато недостатньо вивчених аспектів, що потребує подальших спеціальних досліджень.

\section{ЛITЕРАТУРА:}

Popova O., Guzenko N. Preparation of a future teacher of humanitarian profile for moral education of pupils in the conditions of the new Ukranian school. Theory and Practice of Future Teacher's Training for Work in New Ukrainian School: monograph. Prague, OKTAN PRINT s.r.o., 2020. P. 377-386.

Андрєєв М.В. Теоретичні основи формування педагогічної толерантності вчителів. Гуманізація навчально-виховного процесу : зб. наук. праць. Слов'янськ : СДПУ, 2006. Вип. ХХХ. С. 3-7.

Ахкиямова Г. Подготовка педагога к воспитанию межнациональной толерантности. URL : https://cyberleninka.ru/article/n/podgotovka-pedagoga-k-vospitaniyu-mezhnatsionalnoytolerantnosti

Безюлева Г. В., Бондырева С. К., Шеламова Г. М. Толерантность в пространстве образования : Учеб. пособие. М : МПСИ, 2005. 152 с

Біда О. А. Підготовка майбутніх учителів до формування толерантності в учнів основної школи. Наукові записки. Серія: Педагогічні науки. 2017. Вип. 156. URL : https://www.cuspu.edu.ua/images/download-files/naukovi-zapysky/156/4.pdf

Гончаренко С. У. Український педагогічний словник. К. : Либідь, 1997. 376 с. 
Гончаров Д. О. Суть і структура готовності майбутнього вчителя до виховної роботи. Актуальні проблеми державного управління, педагогіки та психології : зб. наук. праць. Херсон : Херсон. нац. тех. ун-т, 2013. Вип. 1 (8). С. 257-261.

Грива О. А. Толерантність молоді в полікультурному середовищі: [Монографія]. К. : Видавництво Національного педагогічного університету імені М. П. Драгоманова, 2007. 275 c.

Декларація принципів толерантності. [Проголошена та підписана 16 листопада 1995 р.]. Париж: ООН, 1996. 16 с.

Корец В. В., Никитина Г. В., Романенко В. Н. Формирование толерантного поведения у педагога и ученика. Успехи современного естествознания. 2009. № 8. С. 91-94.

Кострубань Р. В. Формування толерантності у майбутніх учителів у процесі гуманітарної підготовки у педагогічних коледжах: автореф. дис. ... канд. пед. наук : 13.00 .04 «Теорія та методика професійної освіти». Хмельницький, 2016. 20 с.

Погодина А. А. Подготовка будущих педагогов к воспитанию толерантности у школьников : автореф. ... дис. канд. пед. наук. : 13.00.08. Ярославль, 2006. URL : https://www.dissercat.com/content/podgotovka-budushchikh-pedagogov-k-vospitaniyutolerantnosti-u-shkolnikov

Психология : словар. [Под ред. А. В. Петровского, М. Г. Ярошевского]. М. : ИПЛ, 1990. 494с.

Ремньова А. Г. Підготовка майбутніх вчителів до виховання толерантності в учнів засобами педагогічних дисциплін. http://enpuir.npu.edu.ua/bitstream/123456789/17876/1/Remnova.pdf

Тодоровцева Ю. В. Педагогіка толерантності : методичні рекомендації. Одеса : СВД Черкасов М. П., 2004. 90 с.

Третьякова А. Н. Формирование толерантности у студентов, специализирующихся в сфере сервиса и туризма как профессионально значимого качества личности : автореф. дис. ... канд педа. наук : 19.00.07 Педагогическая психология. М., 2009. 20 с.

Философский энциклопедический словар. Ред.-сост. Е. Ф. Губский [и др.]. М. : Инфра, 1999. $575 \mathrm{c}$.

Чередник Л. Модель формування у майбутніх учителів готовності до толерантного виховання молодших школярів. Педагогіка формування творчої особистості у вищій $i$ загальноосвітній школах : зб. наук. праць. Запоріжжя : Класич. приват. ун-т. 2019. № 66, T.2. C. 166-171.

\section{REFERENCES:}

Andrieiev, M. V. (2006). Teoretychni osnovy formuvannia pedahohichnoi tolerantnosti vchyteliv [Theoretical bases of teachers' pedagogical tolerance formation]. Humanizatsiia navchalnovykhovnoho protsesu - Humanization of the educational process, XXX, 3-7. Sloviansk : SDPU (in Ukrainian).

Akhkyiamova, H. (n. d.) Podhotovka pedahoha $\mathrm{k}$ vospytaniiu mezhnatsionalnoi tolerantnosti [Preparing a teacher for fostering interethnic tolerance]. URL : https://cyberleninka.ru/article/n/podgotovka-pedagoga-k-vospitaniyu-mezhnatsionalnoytolerantnosti (in Russian).

Beziuleva, H. V., Bondyreva, S. K. \& Shelamova, H. M. (2005). Tolerantnost v prostranstve obrazovaniia [Tolerance in the space of education]. M. : MPSI (in Russian).

Bida, O. A. (2017). Pidhotovka maibutnikh uchyteliv do formuvannia tolerantnosti v uchniv osnovnoi shkoly [Preparing future teachers for the tolerance formation of primary school children]. Naukovi zapysky - Scientific notes. Series: Pedagogical sciences, 156. URL: https://www.cuspu.edu.ua/images/download-files/naukovi-zapysky/156/4.pdf (in Ukrainian). 
Honcharenko, S. U. (1997). Ukrainskyi pedahohichnyi slovnyk [Ukrainian pedagogical dictionary]. K. : Lybid (in Ukrainian).

Honcharov, D. O. (2013). Sut i struktura hotovnosti maibutnoho vchytelia do vykhovnoi roboty [The essence and structure of the future teacher's readiness for educational work]. Aktualni problemy derzhavnoho upravlinnia, pedahohiky ta psykholohii-Actual problems of public administration, pedagogy and psychology, 1 (8), pp. 257-261. Kherson : Kherson. nats. tekh. un-t (in Ukrainian).

Hryva, O. A. (2007). Tolerantnist molodi v polikulturnomu seredovyshchi [Youth's tolerance in multicultural environment]. K. : Vydavnytstvo Natsionalnoho pedahohichnoho universytetu imeni M. P. Drahomanova (in Ukrainian).

Deklaratsiia pryntsypiv tolerantnosti (1996). [Declaration of Principles of Tlerance]. Proholoshena ta pidpysana 16 lystopada 1995 r. [Proclaimed and signed on November 16, 1995]. Paryzh : OON (in Ukrainian).

Korets, V. V., Nikitina H. V. \& Romanenko V. N. (2009). Formirovanie tolerantnoho povedenyia u pedahoha i uchenyka [Formation of tolerant behavior of teacher and student]. Uspekhi sovremennoho estestvoznanyia - Successes of modern natural science, 8. pp. 91-94 (in Russian).

Kostruban, R. V. (2016). Formuvannia tolerantnosti u maibutnikh uchyteliv u protsesi humanitarnoi pidhotovky u pedahohichnykh koledzhakh [Formation of tolerance of future teachers in the process of humanitarian training in pedagogical colleges]. Extended abstract of candidate's thesis. Khmelnytskyi (in Ukrainian).

Pohodyna, A. A. (2006). Podhotovka budushchikh pedahohov $\mathrm{k}$ vospitaniiu tolerantnosti u shkolnikov [Preparing future teachers to foster tolerance among schoolchildren]. Extended abstract of candidate's thesis. Yaroslavl. URL : https://www.dissercat.com/content/podgotovka-budushchikh-pedagogov-k-vospitaniyutolerantnosti-u-shkolnikov (in Russian).

Petrovskii, A. V. \& Yaroshevskii, M. H. (Ed.). (1990). Psikholohiia [Psychology]. M. : IPL (in Russian).

Remnyova, A. H. (n. d.). Pidhotovka maibutnikh vchyteliv do vykhovannia tolerantnosti v uchniv zasobamy pedahohichnykh dystsyplin [Preparation of future teachers for schoolchildren tolerance education by means of pedagogical disciplines]. URL: http://enpuir.npu.edu.ua/bitstream/123456789/17876/1/Remnova.pdf (in Ukrainian).

Todorovtseva, Y. V. (2004). Pedahohika tolerantnosti [Pedagogy of tolerance]. Odesa : SVD Cherkasov M. P. (in Ukrainian).

Tretiakova, A. N. (2009). Formirovanie tolerantnosti u studentov, spetsializiruiushchikhsia v sfere servisa i turizma kak professyonalno znachimoho kachestva lichnosti [Formation of tolerance among students specializing in the field of service and tourism as a professionally significant personality trait]. Extended abstract of candidate's thesis. Moskva (in Russian).

Gubskii, E. F. (Eds.). (1999). Filosofskiy entsiklopedicheskiy slovar [Philosophical Encyclopedic Dictionary]. M. : Infra (in Russian).

Cherednyk, L. (2019). Model formuvannia u maibutnikh uchyteliv hotovnosti do tolerantnoho vykhovannia molodshykh shkoliariv. [The model of formation of future teachers' readiness for tolerant education of primary schoolchildren]. Pedahohika formuvannia tvorchoi osobystosti $u$ vyshchii $i$ zahalnoosvitnii shkolakh - Pedagogy of formation of creative personality in higher and general education schools, 66 (Vols. 2), (pp. 166-171). Zaporizhzhia : Klasych. pryvat. un-t (in Ukrainian).

Popova, O. \& Guzenko, N. (2020). Preparation of a future teacher of humanitarian profile for moral education of pupils in the conditions of the new Ukranian school. Theory and Practice of Future Teacher's Training for Work in New Ukrainian School. Prague, OKTAN PRINT s.r.o., 377-386. 
Інформація про авторів:

Попова Олена Володимирівна

ORCID: http://orcid.org/0000-0003-16115956; доктор педагогічних наук, професор, професор кафедри педагогіки, Харківський національний педагогічний університет

імені Г. С. Сковороди, вул. Алчевських, 29, Харків, Україна, 61002

e-mail: tubaeva@gmail.com

\section{Жуков Василь Павлович}

ORCID: http://orcid.org/0000-0002-7845-6222 ; старший викладач кафедри музичноінструментальної підготовки вчителя, заступник декана 3 виховної роботи факультету мистецтв, Харківський національний педагогічний університет імені Г. С. Сковороди, вул. Алчевських, 29, Харків, Україна, 61002

e-mail: vasil2791@gmail.com
Information about the authors:

\section{Popova Olena Volodymyrivna:}

ORCID: http://orcid.org/0000-0003-1611-

5956; Doctor of Pedagogical Sciences,

Professor, Professor of the Department of

Pedagogy, H. S. Skovoroda Kharkiv National

Pedagogical University, Alchevskykh Street, 29, Kharkiv, Ukraine, 61002

e-mail: tubaeva@gmail.com

\section{Zhukov Vasyl Pavlovych}

ORCID: http://orcid.org/0000-0002-78456222; Senior Lecturer of the Department of Musical and Instrumental Teacher Training, Deputy Dean for Educational Work of the Faculty of Arts, H. S. Skovoroda Kharkiv National Pedagogical University, Alchevskykh Street, 29, Kharkiv, Ukraine, 61002

e-mail: vasi12791@gmail.com

Цитуйте цю статтю як: Попова О.В., Жуков В.П. Педагогічне забезпечення процесу підготовки майбутніх учителів до виховання толерантності школярів. Теорія та методика навчання та виховання. 2020. № 49. С. 67-79. DOI: https://doi.org/10.34142/23128046.2020.49.06

Дата надходження статті до редакції: 2.11.2020 p.

Стаття прийнята до друку: 17.11.2020 p. 